\title{
PHOTOCHEMICAL ACTIVITY OF PRIMARY LEAVES IN CADMIUM STRESSED PHASEOLUS COCCINEUS DEPENDS ON THEIR GROWTH STAGES
}

\author{
EWA SKÓRZYŃSKA-POLIT, TADEUSZ BASZYŃSKI \\ Department of Plant Physiology, Maria Curie-Skłodowska University, \\ 20-033 Lublin, Akademicka 19, Poland
}

(Received: April 12, 1995. Accepted: July 18, 1995)

\begin{abstract}
Runner bean plants (Phaseolus coccineus L., cv. Piękny Jaś) grown hydroponically were treated with $\mathrm{Cd}\left(2.5 \cdot 10^{-5} \mathrm{M} \mathrm{Cd}\right.$ in the form of $3 \mathrm{CdSO}_{4} \cdot 8 \mathrm{H}_{2} \mathrm{O}$ ) at different stages of primary leaves development. Ten days after the metal treatment, the changes in leaf growth parameters and their PSII photochemistry were investigated. The younger were the plants exposed to $\mathrm{Cd}$ (at the initial growth stage of primary leaves) the stronger was the leaf area reduction, fresh weight decrease and increase of plastid pigment level. These changes were correlated with lower level of photosynthetic $\mathrm{O}_{2}$ evolution ( $75 \%$ of control) but chlorophyll a fluorescence measurements suggested an inhibitory effect of $\mathrm{Cd}$ on the acceptor side of PSII. With the development of primary leaves the sensitivity of plants to $\mathrm{Cd}$ increased. $\mathrm{Cd}$ treatment of plants at the final growth stage of the primary leaves caused slight changes in growth parameters compared with control, whereas the chlorophyll content and PSII activity ( $48 \%$ of control) significantly decreased. Analyses of fast chlorophyll a fluorescence kinetics revealed changes suggesting Cd-induced alterations of PSII complex extending on to their acceptor side and the reaction centre. Differential response of primary leaves to $\mathrm{Cd}$ depending on their growth stages indicated alterations of the adaptation mechanism in leaf cells of runner bean plants. The decrease in younger Cd-treated plants of photosynthetic activity was connected with disturbances in growth processes, however in plants treated with $\mathrm{Cd}$ at the final growth stage of the primary leaves it was resulted from destruction of the photosynthetic apparatus.
\end{abstract}

KEY WORDS: Phaseolus coccineus, cadmium, chlorophyll fluorescence, plastid pigments.

\section{INTRODUCTION}

Toxic effect of $\mathrm{Cd}$ on plants has been studied on different levels of their organization. Cd-induced growth inhibition of roots, stems and leaf area as well as disturbances in water relations and stomatal resistance are well documented (Woźny et al. 1990 and references therein, Greger and Johansson 1992, Bishnoi et al. 1993, Moya et al. 1993). Qualitative and quantitative changes in thylakoid membrane composition caused by inhibition of Chl synthesis or its degradation, enhanced hydrolytic enzyme activity or release of polypeptide and acyl lipids in various species of Cd-treated plants were also shown in the last decade (Baszyński et al. 1980, Clijsters and Van

\footnotetext{
List of abbreviations:

Car - carotenoids;

Chl - chlorophyll;

$\mathrm{F}_{\mathrm{o}}, \mathrm{F}_{\mathrm{m}}, \mathrm{F}_{\mathrm{v}}, \mathrm{t}_{1 / 2}$ - initial, maximal, variable fluorescence and half rise time from $F_{o}$ to $F_{m}$;

MGDG - monogalactosyl diacylglycerol;

OEC - oxygen evolving complex;

PPFD - photosynthetic photon flux density;

$\mathrm{R}_{\mathrm{fd}}$ - vitality index.
}

Assche 1985, Krupa and Baszyński 1985, 1989, Baszyński 1986, Padmaya et al. 1990, Parekh et al. 1990, Skórzyńska and Baszyński 1993). These changes affecting photochemical activities of thylakoid membranes were discussed with regard to direct or indirect $\mathrm{Cd}$ action on the light phase of photosynthesis (Clijsters and Van Assche 1985, Baszyński 1986, Greger and Ögren 1991, Krupa et al. 1993, Skórzyńska and Baszyński 1993). Susceptibility of plants to $\mathrm{Cd}$ at various metal concentrations and the time of its action was usually taken into account. However, the problem of Cd toxicity related to plant growth stages has been omitted so far except the experiments of Sheoran et al. (1990) on photosynthesis in Cajanus cajan grown in sand culture and exposed to $\mathrm{Cd}$ and $\mathrm{Ni}$ at different onthogenetic stages. Recently, differentiated response to excess $\mathrm{Cu}$ of the photosynthetic apparatus of runner bean leaves depending on their growth stage was reported (Maksymiec et al. 1994).

The aim of this work is to compare the growth parameters of primary leaves and their photosynthetic activities in hydroponically cultivated runner bean plants supplemented with $\mathrm{Cd}$ at different growth stages. 


\section{MATERIAL AND METHODS}

\section{Plant material}

Runner bean plants (Phaseolus coccineus L., cv. Piękny Jaś) were germinated from seeds on wet filter paper in a thermostated darkened chamber $\left(23^{\circ} \mathrm{C}, 95 \%\right.$ relative humidity). From day 5 the plants were cultivated hydroponically in aerated Knop nutrient solution at $20^{\circ} \mathrm{C}$ and PPFD of $100 \mu \mathrm{mol}$ $\mathrm{m}^{-2} \mathrm{~s}^{-1}$ at a day/night regime of 16/8 hours. Cadmium in the form of $3 \mathrm{CdSO}_{4} \cdot 8 \mathrm{H}_{2} \mathrm{O}$ at a final concentration of $2.5 \cdot 10^{-5} \mathrm{M}$ was added to the nutrient solution at different stages of primary leaves growth, i.e. immediately after seedlings transfer to the nutrient solution (0), and on day 4,6,8 and 10 after this transfer, respectively. The primary leaves of control and Cd-treated plants were harvested for analyses 10 days after the treatment.

Fig. 1 presents the scheme of the examined plant cultivation including the days at which $\mathrm{Cd}$ was applied to the nutrient solution and the action time of the metal the same in all variants. Cd-treated plants were compared with control being of the same age, i.e. 10, 14, 16, 18 and 20 days old, respectively.

\section{Photochemical activity of chloroplasts}

For measurements of PSII activity intact chloroplasts were isolated according to Muńoz-Rueda et al. (1986). Photosynthetic $\mathrm{O}_{2}$ evolution $\left(\mathrm{H}_{2} \mathrm{O} \rightarrow \mathrm{FeCN}_{6}\right)$ was determined using the basal medium described by Maksymiec and Baszyński (1988) and a Hansatech DW2 oxygen electrode coupled to a Hansatech IF1/2 computer interface board and DRS1 software.

\section{Measurements of chlorophyll fluorescence}

The fast $\mathrm{Chl}$ fluorescence induction kinetics were measured in primary leaves using a Plant Stress Meter (BioMonitor, Sweden). Prior to the measurements, the plants were dark-adapted for $60 \mathrm{~min}$ in order to "relax" all energy-dependent fluorescence quenching.

The slow phase of the Kautsky curve was recorded using the Plant Stress Meter attached to an IBM compatible computer via IF/1 interface board (Hansatech Instruments Ltd., King's Lynn, UK) and controlled by the Hansatech DRS1 data aquisition software.

The $R_{\mathrm{fd}}$ values (so-called "vitality indexes") were calculated according to Lichtenthaler and Rinderle (1988).

\section{Other determinations}

Chlorophyll and carotenoids were estimated in $80 \%$ acetone leaf extracts according to Lichtenthaler and Wellburn (1983).

The areas of leaves were measured using Geniscan GS4500 scanner (Genius, Taiwan) and dedicated area measuring computer software manufactured by Witra (Warsaw, Poland). The specific leaf area was defined as leaf area per fresh weight unit.

The Cd concentration was determined by atomic absorption spectrophotometry (Pye Unicam SP-9, Cambridge, UK) after wet-ashing of the dried material in a $\mathrm{HNO}_{3} / \mathrm{HClO}_{4}$ mixture $(4: 1, \mathrm{v} / \mathrm{v})$.

\section{RESULTS}

Responses of runner bean plants to long-term action (10 days) of Cd applied to the nutrient solution depend on the stage of plant growth (Fig. 2.). The plants treated with $\mathrm{Cd}$ at the initial growth stage of primary leaves (on day 0 and 4 after the transfer of plants to the nutrient solution) showed a decrease in the leaf area to $40-50 \%$ of control. Cd application at more advanced growth stages (on day 6 and 8 of plant growth in the nutrient solution) decreased the leaf area to about $70 \%$. The leaf area of plants treated with $\mathrm{Cd}$ at the final growth stage reached $85 \%$ as compared with the control.

Fresh and dry weight of leaves in plants supplied with $\mathrm{Cd}$ at the initial growth stages was about $40 \%$ and $60 \%$ of that of control, respectively (Fig. 3.). Later treatment of plants with $\mathrm{Cd}$ did not change significantly the fresh weight of leaves, whereas their dry weight reached about $75-80 \%$ of the control, which significantly increased the DW/FW ratio in this plant group (Fig. 4.).

The specific leaf area in plants treated with $\mathrm{Cd}$ at the initial growth stage was characterized by its slight decrease (Fig. 4.). However, when $\mathrm{Cd}$ was added to the nutrient solution at the stationary stage of leaf growth the specific leaf area was much higher.

Accumulation of plastid pigments calculated on the basis of leaf area in plants treated with $\mathrm{Cd}$ immediately after their transfer to the nutrient solution increased to about $135 \%$ (Fig. 5.). Later addition of $\mathrm{Cd}$ did not cause significant changes in

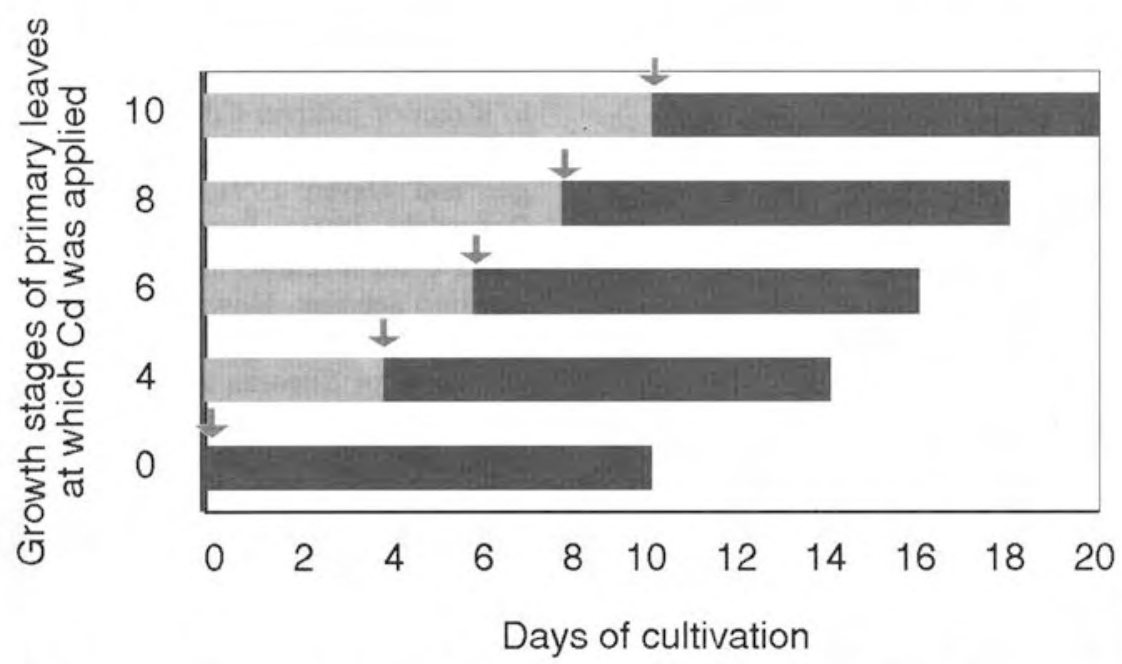

Fig. 1. The scheme of runner bean plants cultivation in the nutrient solution. The plants were treated with Cd at different growth stages of primary leaves, i.e. immediately after seedlings transfer to the nutrient solution (0) and on day 4-(4), 6-(6). 8-(8) and 10-(10) after this transfer. The primary leaves of control and Cd-treated plants were analysed 10 days after the treatment. Arrows indicate the days of the metal treatment. 


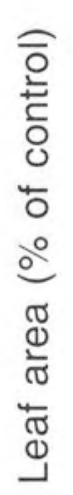

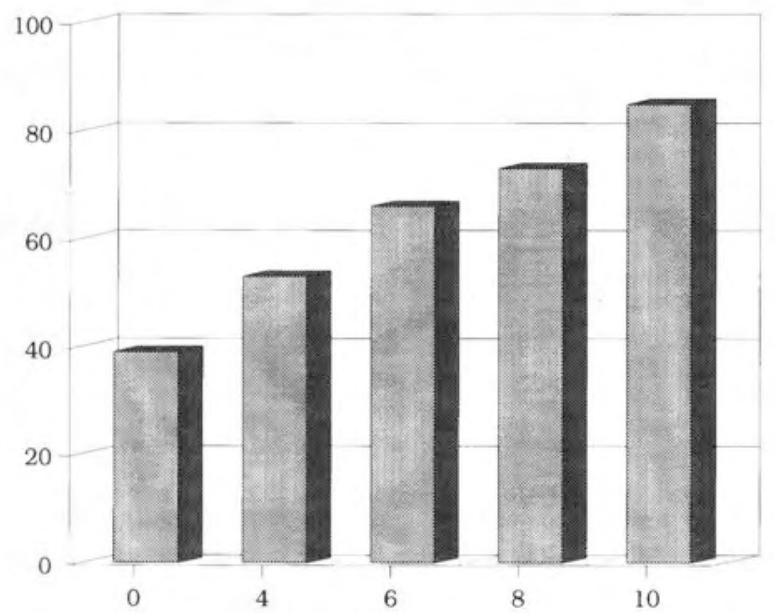

Days of Cd application

Fig. 2. Changes in primary leaf area of runner bean plants after 10 days of $\mathrm{Cd}$ action in relation to different their growth stages $(0,4,6$, 8,10 days without $(\mathrm{d})$ at which the metal was applied to the nutrient solution. Values represent the mean of 10 replicates. SE was equal or lower than $7 \%$.

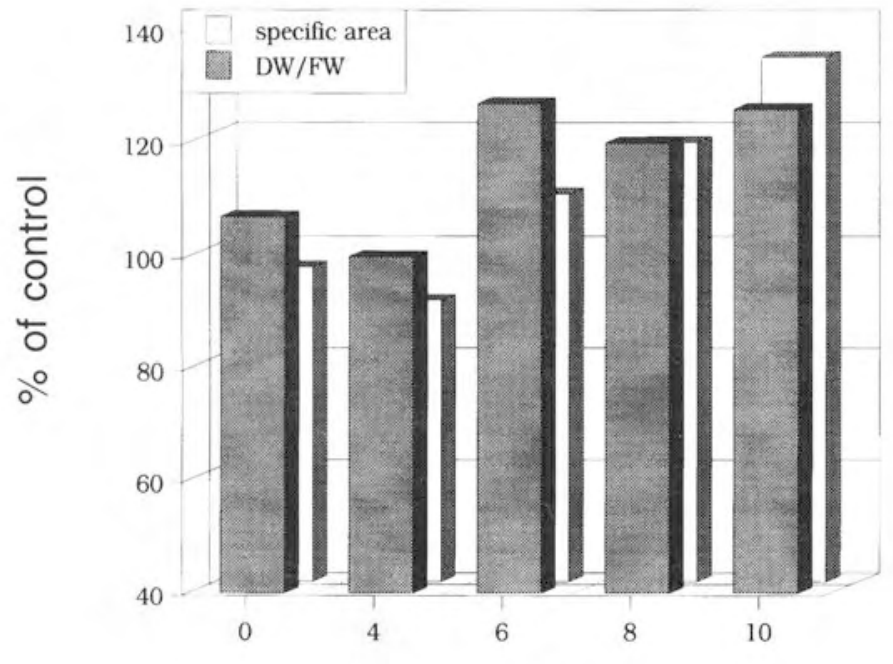

Days of Cd application

Fig. 4. Changes in DW/FW ratio and the specific leaf area of primary leaves in runner bean plants treated with $\mathrm{Cd}$ in relation to the growth stage $(0,4,6,8,10$ days without $\mathrm{Cd})$ at which the metal was applied to the nutrient solution. The plants were analysed 10 days after the treatment. Specific area was defined as leaf area per fresh weight unit. The data are means of 10 replicates. SE was equal or lower than $7 \%$.

accumulation of pigments, the level of which was similar to that in control. Only at the final stage of leaf growth a strong reduction of both pigments, $\mathrm{Chl}$ and $\mathrm{Car}$ to $72 \%$ and $78 \%$, respectively, was observed. At this growth stage the changes of pigment accumulation were accompanied by chlorosis and necrotic changes of the primary leaves.

Changes in the growth parameters of the primary leaves were related to some reduction of $\mathrm{R}_{\mathrm{fd}}$ in the initial growth stage

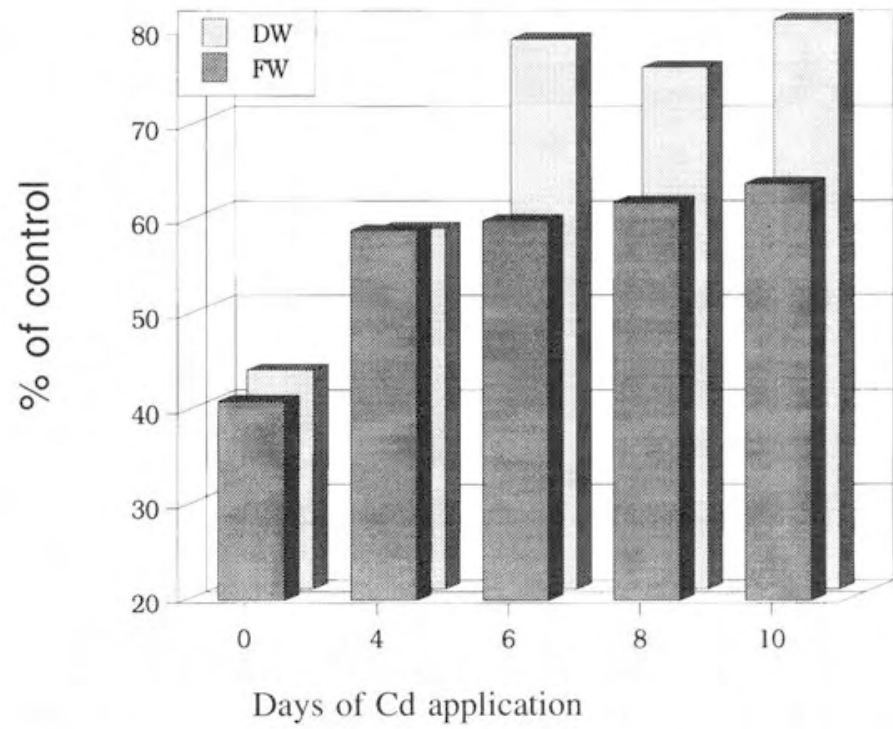

Fig. 3. Changes in fresh and dry weight of primary leaves in runner bean plants treated with $\mathrm{Cd}$ in relation to the growth stage $(0,4,6,8$, 10 days without $\mathrm{Cd}$ ) at which the metal was applied to the nutrient solution. The plants were analysed 10 days after the treatment. The data are means of 10 replicates. SE was equal or lower $8 \%$.

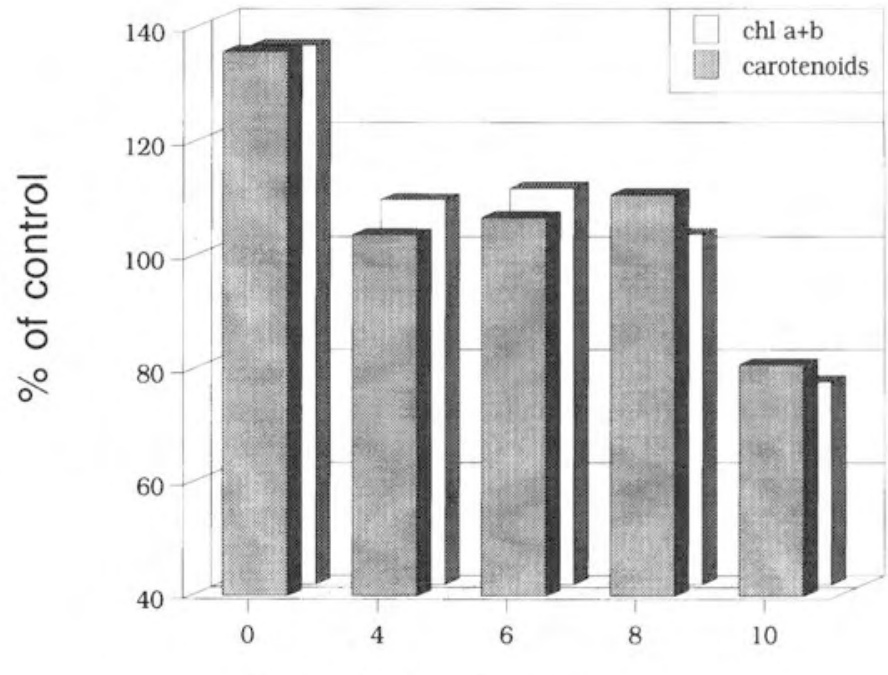

Days of Cd application

Fig. 5. Changes in chloroplast pigments of primary leaves in runner bean plants after 10 days of $\mathrm{Cd}$ action in relation to the leaf growth stage $(0,4,6,8,10$ days without $\mathrm{Cd})$ at which the metal was applied to the nutrient solution. The data are means of 10 replicates. SE was equal or lower than $6 \%$.

( $77 \%$ of control) and a significant drop (33\% of control) in leaves treated with $\mathrm{Cd}$ at the end stage of their growth (Fig. 6.).

$\mathrm{F}_{\mathrm{v}} / \mathrm{F}_{\mathrm{m}}$ values measured for primary leaves of Cd-treated plants were in the typical range for control plants except those of leaves of plants treated with the metal at the final growth stage in which they decreased to $96 \%$ of control (Fig. 6.).

$\mathrm{F}_{\mathrm{v}} / \mathrm{F}_{\mathrm{o}}$ slightly increased in leaves of plants treated with $\mathrm{Cd}$ on day 6 of growth in the nutrient solution and reached a hig- 


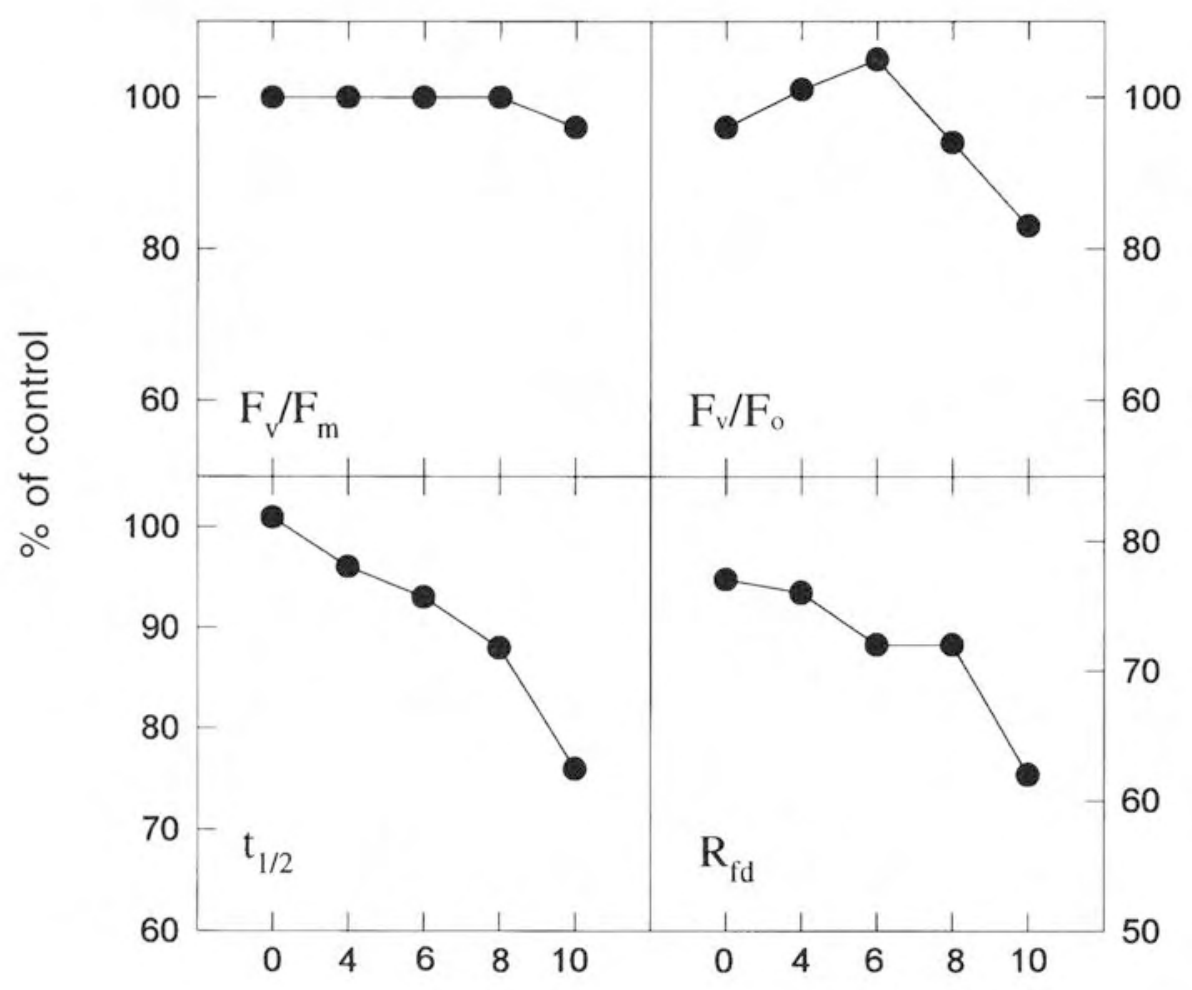

\section{Days of growth at which Cd was added}

Fig. 6. Chlorophyll a fluorescence induction parameters of primary leaves of runner bean plants treated with $\mathrm{Cd}$ at different growth stages $(0,4,6,8,10$ days without $\mathrm{Cd})$. The measurements were made after 10 days of $\mathrm{Cd}$ action. The values are percentages od control. SE was equal or lower than $8 \%$. her value (110\% of control). Afterwards a sharp decline of this ratio due to the period of $\mathrm{Cd}$ application was observed. At the final growth stage of primary leaves it was reduced to about $85 \%$ of control (Fig. 6.).

The parameter $t_{1 / 2}$, which is the half rise time from $F_{0}$ to $\mathrm{F}_{\mathrm{m}}$, unchanged in leaves of plants treated with $\mathrm{Cd}$ immediately after their transfer to the nutrient solution, and gradually decreased during the period of $\mathrm{Cd}$ application. In the oldest plants it reached about $76 \%$ of control (Fig. 6.).

The photosynthetic $\mathrm{O} 2$ evolution of chloroplasts was also dependent on the growth stage of primary leaves. The metal application shows a gradual and significant decrease in this activity to $48 \%$ of control at the final growth stage (Fig. 7.). Although the presence of BSA in the medium used for chloroplast isolation protected to some extent this activity but it never reached the value of control.

$\mathrm{Cd}$ concentrations in primary leaves of plants increased with delayed $\mathrm{Cd}$ application to the nutrient solution. Only at the final growth stage the metal concentration was much lower (Table 1.).

\section{DISCUSSION}

Changes in the growth parameters as well as in the accumulation of plastid pigments and photochemical activities of runner bean plants, after 10 days exposure to $\mathrm{Cd}$, depended on the growth stage of primary leaves in which $\mathrm{Cd}$ was applied to the environment of plant growth.

Cd-induced primary leaf area reduction found in the present studies was reported earlier (Barceló et al. 1986, Poschenrie-

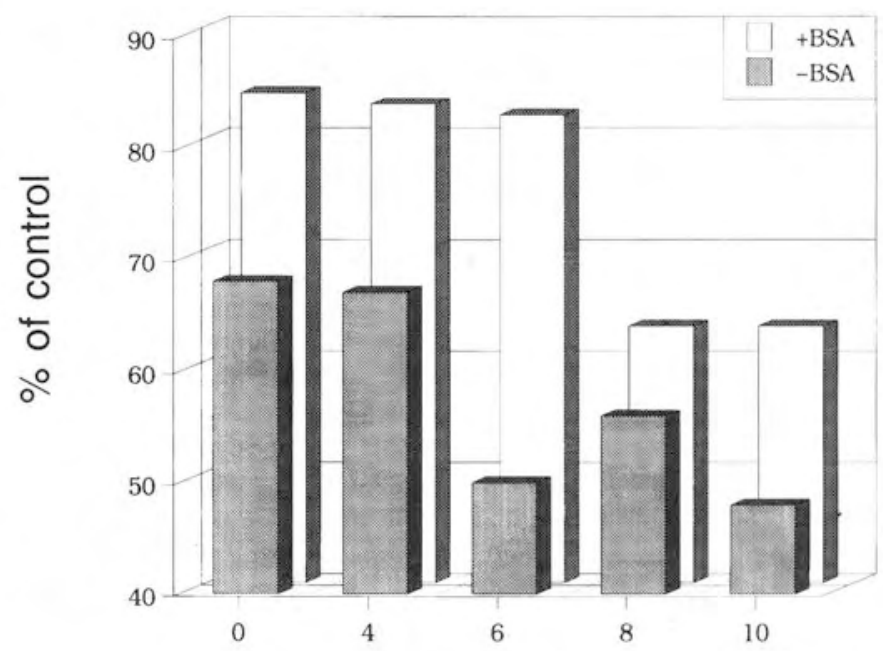

Days of Cd application

Fig. 7. Photosynthetic oxygen evolution by chloroplasts isolated from primary leaves of runner bean plants after 10 days of $\mathrm{Cd}$ action in relation to different their growth stages $(0,4,6,8,10$ days without $\mathrm{Cd}$ ) at which the metal was applied to the nutrient solution. The data are means of 5 experiments. SE values were equal or lower than $8 \%$. 
TABLE 1. Cd content in primary leaves of runner bean plants treated with $\mathrm{Cd}$ at different growth stages and exposed to the metal for 10 days. The values represent the mean $\pm \operatorname{SE}(n=7)$.

\begin{tabular}{c|c}
\hline $\begin{array}{c}\text { Days of growth } \\
\text { at which Cd was applied }\end{array}$ & $\mu \mathrm{g} \cdot \mathrm{g}^{-1}$ dry weight \\
\hline 0 & $45.9 \pm 8.8$ \\
4 & $53.1 \pm 10.6$ \\
6 & $63.9 \pm 6.6$ \\
8 & $63.4 \pm 6.0$ \\
10 & $37.7 \pm 9.5$ \\
\hline
\end{tabular}

der et al. 1989, Krupa et al. 1992, Bishnoi et al. 1993). However, the obtained results allow us to draw further conclusions that the leaf area reduction is variable, the highest in plants treated with $\mathrm{Cd}$ at the earliest growth stage of primary leaves, but it decreases in older Cd-treated plants.

Also the decrease in fresh weight of leaves is the highest at the early growth stages of Cd-treated plants and becomes lower in older plants. Smaller changes in dry weight of the primary leaves of plants treated with $\mathrm{Cd}$ at the early growth stages similar to those of fresh weight and the specific leaf area exclude the possibility of water deficiency in this plant group. On the contrary, increase of the dry weight and specific leaf area found in leves of older plants treated with $\mathrm{Cd}$ suggests that some water deficiency might occurre. This was also confirmed by increased $\mathrm{DW} / \mathrm{FW}$ ratio which indicate symptoms of metal toxicity.

$\mathrm{Cd}$-induced water stress, a main response of plants to $\mathrm{Cd}$ has already been shown (Barceló et al. 1988, Poschenrieder et al. 1989, Greger and Johansson 1992, Moya et al. 1993) and finds support in our results in these series of plants when their leaves were reasonably developed at $\mathrm{Cd}$ application.

Decreased accumulation of plastid pigments found in the present studies is commonly known as a typical symptom of Cd toxic action in plants (Baszyński et al. 1980, Kłobus and Buczek 1985, Krupa et al. 1987, Becerril et al. 1988). However, Barceló et al. (1988), studying Cd effect on the level of plastid pigments in primary and trifoliate leaves of bush bean plants already showed that the first leaves were intensively green, whereas Chl content decreased in the secondary ones. These authors' suggestion that "the differences in the effect of $\mathrm{Cd}$ between leaf types are probably related to the different stages of leaf development, at which they were first exposed to $\mathrm{Cd}$ ", found support in our results. Indeed, plants treated with $\mathrm{Cd}$ at the earliest growth stages showed a high accumulation of $\mathrm{Chl}$ expressed on the basis of leaf area. However, a distinct $\mathrm{Chl}$ decrease as compared to control was observed in plants treated with the metal at the final leaf growth stage.

$\mathrm{Cd}$ accumulation in leaves depended on their growth stage at which the metal was applied to the medium. In plants treated with $\mathrm{Cd}$ at a later growth stage the lowest metal level was found. A slower transport of $\mathrm{Cd}$ taken up from the medium may be connected with water deficiency mentioned above. On the other hand, the transport of $\mathrm{Cd}$ released from necrotic cells of the primary leaves to trifoliate ones cannot be excluded.

A symptom of toxic $\mathrm{Cd}$ action found in all plant groups examined was a lower level of photosynthetic $\mathrm{O}_{2}$ evolution than in control, accompanied by decreased $\mathrm{R}_{\mathrm{fd}}$ accounting for disturbances of the photosynthetic efficiency of leaves (Lich- tenthaler and Rinderle 1988). The intensity of these changes was closely related to the time of $\mathrm{Cd}$ application to the plant growth medium. The later $\mathrm{Cd}$ was applied the bigger the changes were, but the level of photosynthetic $\mathrm{O}_{2}$ evolution decreased more and more. The application of BSA used for isolation of chloroplasts as an agent protective PSII from the action of free fatty acids (Siegenthaler 1973), did not give the expected effects in any of the plant group studied, although photochemical activities closest to control were obtained for plants treated with $\mathrm{Cd}$ at the earlier growth stages.

The results of photosynthetic $\mathrm{O}_{2}$ evolution and the fluorescence parameters suggest different causes of PSII activity decrease. In plants treated with $\mathrm{Cd}$ at the earlier growth stages of primary leaves a low PSII activity level could be due to the action of free fatty acids, which inhibitory effect on PSII activity had been often found (Krogmann and Jagendorf 1958, Siegenthaler 1973, Goldbeck et al. 1980). The appearance of free fatty acids resulted from enhanced galactolipase activity degrading MGDG, as well as dissociation of OEC polypeptides, which may cause a low PSII activity in Cd-treated plants, were demonstrated earlier (Skórzyńska et al. 1991, Skórzyńska and Baszyński 1993). Such a possibility may be accounted for by lack of changes in the inner PSII structure, resulting from measurements of $\mathrm{Chl}$ a fluorescence and the absence of significant changes in $\mathrm{Chl}$ a fluorescence induction parameters at the early growth stages of plants treated with Cd and Ni (Krupa et al. 1992, 1993) or with excess Cu (Maksymiec et al. 1994), was presented elsewhere. It cannot be excluded that low PSII activity is affected by impeded gas exchange in spongy mesophyll cells of the leaf because of reduction sizes of spongy mesophyll cells and intercellular spaces under $\mathrm{Cd}$ influence as it has already been found (Barceló et al. 1988, Greger and Johansson 1992, Skórzyńska-Polit et al. 1995).

Gradual decrease in photosynthetic $\mathrm{O}_{2}$ evolution, strongly expressed in plants treated with $\mathrm{Cd}$ at the final leaf growth stage, might result from the action of several factors. Sheoran et al. (1990a, b) and Bishnoi et al. (1993) suggested that reduction in photosynthesis under $\mathrm{Cd}$ treatment could not be ascribed exclusively to reduced $\mathrm{Chl}$, but it might result from decreased availability of water.

Decreased $F_{v} / F_{0}$ ratio, $t_{1 / 2}$ and a little drop of $F_{v} / F_{m}$ found in the present work support the earlier observations (Krupa et al. 1992) and indicate more intense changes in the structure of PSII complex. Changes of these parameters may reflect reduction of the effective antenna size of PSII, a block at the level of $\mathrm{D}_{1}$ protein or diminished pool of PQ (Krause and Weis 1984, Öquist and Wass 1988). Decreased $F_{v} / F_{o}$ may point to disturbances in photosynthetic electron transport or damage of the thylakoid structure on the donor side of PSII (Havaux and Lannoye 1984, Ouzounidou 1993). Maksymiec et al. (1994), studying the effect of excess $\mathrm{Cu}$ on the photosynthetic apparatus of plants at their final intensive growth stage, obtained similar results and found changes in the polypeptide composition of OEC and PSII internal antenna. Many researchers have pointed to the donor side of PSII as the primary site of toxic action of heavy metals (for review see Baszyński 1986).

Summing up, the inhibitory mechanism of PSII activity seems to depend on the time of $\mathrm{Cd}$ application to the plant growth medium. In plants treated with $\mathrm{Cd}$ at the early growth stages of the primary leaves, photosynthetic $\mathrm{O}_{2}$ evolution decrease should be associated with changes in OEC complex, $i$. $e$. on the donor side of PSII, and with impeded gas exchange of leaves what is correlated with reduction of leaf area. 
In plants treated with $\mathrm{Cd}$ at later growth stages, the rate of PSII activity is affected by water deficiency and progressing degradation of PSII complex structure extending to its acceptor side, and probably to its centre.

Leaves at the early growth stage seem to be more resistant to Cd. Changes in cell metabolism allow these plants to survive despite the presence of the toxic metal in their growth conditions. The older leaves with constituted cell metabolism are more sensitive to $\mathrm{Cd}$. The operating adaptation mechanisms in these leaves are probably inefficient to reduce $\mathrm{Cd}$ toxic action, which leads to destruction of their photosynthetic apparatus.

\section{ACKNOWLEDGEMENTS}

This work is a part of a project supported by the Polish Committee for Scientific Research (KBN) grant No 6 P204 09904.

\section{LITERATURE CITED}

BARCELÓ J., POSCHENRIEDER CH., ANDREU I., GUNSÉ B., 1986. Cadmium-induced decrease of water stress resistance in bush bean plants (Phaseolus vulgaris L. cv. Contender). I. Effect of $\mathrm{Cd}$ on water potential, relative water content and cell wall elasticity. J. Plant Physiol. 125: 17-25.

BARCELÓ J., VAZQUEZ M.D., POSCHENRIEDER CH., 1988. Structural and ultrastructural disorders in cadmium-treated bush plants (Phaseolus vulgaris L.). New Phytol. 108: 37-49.

BASZYŃSKI T., 1986. Interference of $\mathrm{Cd}^{2+}$ in functioning of the photosynthetic apparatus of higher plants. Acta Soc. Bot. Pol . 55: 291301 .

BASZYŃSKI T., WAJDA L., KRÓL M., WOLIŃSKA D., KRUPA Z., TUKENDORF A., 1980. Photosynthetic activities of cadmium treated tomato plants. Physiol. Pant. 48: 365-370.

BISHNOI N.R., SHEORAN I.S., SINGH R., 1993. Influence of cadmium and nickel on photosynthesis and water relations in wheat leaves at different insertion level. Photosynthetica 28: 473-479.

BECERRIL J.M., MUŃOZ-RUEDA A., APARICIO-TEJO P., GONZALEZ-MURUA C., 1988. The effects of cadmium and lead on photosynthetic electron transport in clover and lucerne. Plant Physiol. Biochem. 25: 357-363,

CLIJSTERS H., VAN ASSCHE F., 1985. Inhibition of photosynthesis by heavy metals. Photosynth. Res. 7: 31-40.

GOLDBECK J.H., MARTIN I.F., FOWLER C.F., 1980. Mechanism of linolenic acid- induced inhibition of photosynthetic electron transport. Plant Physiol. 65: 707-713.

GREGER M., ÖGREN E., 1991. Direct and indirect effects of $\mathrm{Cd}^{2+}$ on photosynthesis in sugar beet (Beta vulgaris). Physiol. Plant. 83: 129135.

GREGER M., JOHANSSON M ., 1992. Cadmium effects on leaf transpiration of sugar beet (Beta vulgaris). Physiol. Plant. 86: 465-473.

HAVAUX M., LANNOYE R., 1984. Effects of chilling temperatures on prompt and delayed chlorophyll fluorescence in maize and barley leaves. Photosynthetica 18: 117-127.

KŁOBUS G., BUCZEK J., 1985. Chlorophyll content cells and chloroplasts number and cadmium distribution in Cd-treated cucumber plants. Acta Physiol. Plant. 7: 139-147.

KRAUSE G.H., WEIS E., 1984. Chlorophyll fluorescence and photosynthesis: The basics. Annu. Rev. Plant Physiol. Plant Mol. Biol. 42: 313-349

KROGMANN D.W., JAGENDORF A.T., 1958. Inhibition of the Hill reaction by fatty acid and metal chelating agents. Arch. Biochem . Biophys. 80: 421-430.
KRUPA Z., BASZYŃSKI T., 1985. Effects of cadmium on the acyl lipid content and fatty acid composition in thylakoid membranes isolated from tomato plants. Acta Physiol. Plant. 7: 55-64.

KRUPA Z., BASZYŃSKI T., 1989. Acyl lipid composition of thylakoid membranes of cadmium-treated tomato plants. Acta Physiol. Plant. 11: 111-116.

KRUPA Z., SKÓRZYŃSKA E., MAKSYMIEC W., BASZYŃSKI T., 1987. Effect of cadmium treatment on the photosynthetic apparatus and its photochemical activities in greening seedlings. Photosynthetica 23: 695-698.

KRUPA Z., ÖQUIST G., HUNER N.P.A., 1992. The influence of cadmium on primary photosystem II photochemistry in bean as revealed by chlorophyll a fluorescence - a preliminary study. Acta Physiol. Plant. 14: 71-76.

KRUPA Z., ÖQUIST G., HUNER N.P.A., 1993. The effects of cadmium on photosynthesis of Phaseolus vulgaris - a fluorescence analysis. Physiol. Plant. 88: 626-630.

LICHTENTHALER H.K., WELLBURN R.R., 1983. Determination of total carotenoids and chlorophylls a and b of extracts in different solvents. Biochem. Soc. Trans. 603:591- 592.

LICHTENTHALER H.K., RINDERLE U., 1988. The role of chlorophyll fluorescence in the detection of stress conditions in plants. CRC Crit. Rev. Anal. Chem. 19: S29-S85.

MAKSYMIEC W., BASZYŃSKI T., 1988. The effect of $\mathrm{Cd}^{2+}$ on the release of proteins from thylakoid membranes of tomato leaves. Acta Soc. Bot. Pol. 57: 465-474.

MAKSYMIEC W., RUSSA R., URBANIK-SYPNIEWSKA T., BASZYŃSKI T., 1994. Effect of excess Cu on the photosynthetic apparatus of runner bean leaves treated at two different growth stages. Physiol. Plant. 91: 715-721.

MOYA J.L., ROS R., PICAZO I., 1993. Influence of cadmium and nickel on growth, net photosynthesis and carbohydrate distribution in rice plants. Photosynth. Res. 36: 75- 80.

MUÑOZ-RUEDA A., GONZALEZ-MURUA C., BECERRIL J.M. SANCHEZ-DIAZ M.F., 1986. Effects of glyphosate [N-(phosphonomethyl)glycine] on photosynthetic pigments, stomatal response and photosynthetic electron transport in Medicago sativa and Trifolium pratense. Physiol. Plant. 66: 63-68.

OUZOUNIDOU G., 1993. Changes in variable chlorophyll fluorescence as a result of $\mathrm{Cu}$ - treatment: Dose-response relations in Silene and Thlaspi. Photosynthetica 29: 455-462.

PADMAJA K., PRASAD D.D.K., PRASAD A.R.K., 1990. Inhibition of chlorophyll synthesis in Phaseoulus vulgaris L. seedling by cadmium acetate. Photosynthetica 24: 399-405.

PAREKH D., PURANIK R.M., SRIVASTAVA H.S., 1990. Inhibition of chlorophyll biosynthesis by cadmium in greening maize leaf segments. Biochem. Physiol. Pflanzen. 186: 239-242.

POSCHENRIEDER CH., GUNSÉ B., BARCELÓ J., 1989. Influence of cadmium on water relations, stomatal resistance, and abscisic acid content in expanding bean leaves. Plant Physiol. 90: 1365-1371.

QUIST G., WASS R., 1988. A portable, microprocessor operated instrument for measuring chlorophyll fluorescence kinetics in stress physiology. Physiol. Plant. 73: 211-217.

SHEORAN I.S., SINGAL H.L., SINGH R., 1990a. Effect of cadmium and nickel on photosynthesis and the enzymes of the photosynthetic carbon reduction cycle in pigeonpea (Cajanus cajan L.). Photosynth. Res. 23: 345-351.

SHEORAN I.S., AGGARWAL N., SINGH R., 1990b. Effects of cadmium and nickel on in vivo carbon dioxide exchange rate of pigeon pea (Cajanus cajan L.). Plant Soil. 129: 243-249.

SIEGENTHALER P., 1973. Changes in $\mathrm{pH}$ dependence and seqential inhibition of photosynthetic activity in chloroplasts by unsaturated fatty acids. Biochem. Biophys. Acta 305: 153-162.

SKÓRZYŃSKA E., URBANIK-SYPNIEWSKA T., RUSSA R., BASZYŃSKI T., 1991. Galactolipase activity in Cd-treated runner bean plants. J. Plant Physiol. 138: 454-459.

SKÓRZYŃSKA E., BASZYŃSKI T., 1993. The changes in PSII complex polypeptides under cadmium treatment - are they direct or indirect nature? Acta Physiol. Plant. 15: 263-269. 
SKÓRZYŃSKA-POLIT E., BEDNARA J., BASZYŃSKI T., 1995. Some aspects of runner bean plants response to cadmium at different stages of the primary laef growth. Acta Soc. Bot. Pol. 64: 165-170.
WOŹNY A., STROIŃSKI A., GWÓŹDŹE., 1990. Plant cell responses to cadmium. Wydawnictwo Naukowe Uniwersytetu im. Adama Mickiewicza. Poznań.

\section{AKTYWNOŚĆ FOTOCHEMICZNA PIERWSZYCH LIŚCI FASOLI PHASEOLUS COCCINEUS TRAKTOWANEJ KADMEM ZALEŻY OD STADIUM ICH WZROSTU}

\section{STRESZCZENIE}

Fasolę (Phaseolus coccineus odm. Piękny Jaś) uprawianą na pożywce Knopa traktowano Cd $(2.5 \cdot 10-5$ $\mathrm{Cd}$ w formie $3 \mathrm{H}_{2} \mathrm{O} \cdot 8 \mathrm{H}_{2} \mathrm{O}$ ) w różnych stadiach wzrostu pierwszych liści. Po 10 dniach działania metalu badano parametry wzrostu liści i ich aktywność fotochemiczną. Młodsze rośliny (poddane działaniu Cd w początkowym stadium wzrostu pierwszych liści) wykazywały silniejszą redukcję blaszki liściowej i świeżej masy oraz wzrost poziomu barwników chloroplastowych. Zmiany te skorelowane były ze zmiejszeniem się poziomu fotosyntetycznego wydzielania tlenu (75\% wartości kontrolnej), a pomiar poziomu fluorescencji chlorofilu a sugerował inhibujący wpływ Cd po akceptorowej stronie PSII.

Wraz z rozwojem pierwszych liści wrażliwość roślin na Cd wzrastała. Rośliny traktowane Cd w późniejszym stadium wzrostu pierwszych liści wykazywały mniejsze zmiany w parametrach wzrostu w porównaniu z kontrolą, ale wyraźniejszy spadek zawartości chlorofilu i aktywności PSII (48\% wartości kontrolnej). Analiza krzywej kinetyki szybkiej fazy fluorescencji sugeruje zaburzenia w kompleksie PSII, wywołane działaniem Cd, rozszerzające się na stronę akceptorową i centrum reakcji PSII. Zróżnicowana odpowiedź pierwszych liści fasoli na $\mathrm{Cd}$, zależna od stadium ich wzrostu wskazuje na różnice w mechnizmie adaptacyjnym komórek liści fasoli. U roślin młodszych poddanych działaniu Cd zmiejszenie aktywności fotosyntetycznej należy wiązać raczej z zakłóceniem procesów wzrostowych, natomiast u roślin traktowanych $\mathrm{Cd}$ w końcowej fazie wzrostu pierwszych liści, związane jest z destrukcją ich aparatu fotosyntetycznego.

SŁOWA KLUCZOWE: Phaseolus coccineus, kadm, fluorescencja chlorofilu, barwniki plastydowe. 